\title{
The Emerging Role of Chromatin Remodeling Factors in Female Pubertal Development
}

\author{
Carlos Francisco Aylwin Katinka Vigh-Conrad Alejandro Lomniczi
}

Division of Genetics, Oregon National Primate Research Center, Oregon Health and Science University (OHSU), Beaverton, OR, USA

\section{Keywords}

Epigenetics $\cdot$ Puberty $\cdot$ Kiss $1 \cdot$ GnRH

\begin{abstract}
To attain sexual competence, all mammalian species go through puberty, a maturational period during which body growth and development of secondary sexual characteristics occur. Puberty begins when the diurnal pulsatile gonadotropin-releasing hormone $(\mathrm{GnRH})$ release from the hypothalamus increases for a prolonged period of time, driving the adenohypophysis to increase the pulsatile release of luteinizing hormone with diurnal periodicity. Increased pubertal GnRH secretion does not appear to be driven by inherent changes in GnRH neuronal activity; rather, it is induced by changes in transsynaptic and glial inputs to GnRH neurons. We now know that these changes involve a reduction in inhibitory transsynaptic inputs combined with increased transsynaptic and glial excitatory inputs to the GnRH neuronal network. Although the pubertal process is known to have a strong genetic component, during the last several years, epigenetics has been implicated as a significant regulatory mechanism through which GnRH release is first repressed before puberty and is involved later on during the increase
\end{abstract}

\section{KARGER}

(๑) 2019 S. Karger AG, Basel

E-Mail karger@karger.com

www.karger.com/nen in GnRH secretion that brings about the pubertal process. According to this concept, a central target of epigenetic regulation is the transcriptional machinery of neurons implicated in stimulating $\mathrm{GnRH}$ release. Here, we will briefly review the hormonal changes associated with the advent of female puberty and the role that excitatory transsynaptic inputs have in this process. In addition, we will examine the 3 major groups of epigenetic modifying enzymes expressed in the neuroendocrine hypothalamus, which was recently shown to be involved in pubertal development and progression.

(c) 2019 S. Karger AG, Basel

\section{Introduction}

The first endocrine indication of the initiation of puberty is an increase in pulsatile luteinizing hormone (LH) release $[1,2]$. In girls, plasmatic LH pulse frequency increases after the initiation of sleep during the early puberty phase, even before any somatic manifestation becomes evident and given the lack of changes in circulating ovarian steroids. In rodents, increased LH pulse amplitude is also ovary independent and occurs in the afternoon by the end of the juvenile period $[3,4]$. Elevated 
plasma LH levels increase gonadal sex steroid production, leading to the development of secondary sexual characteristics. In females, upon maturation of the central mechanism of estrogen-positive feedback, the first preovulatory surge of gonadotropins occurs followed by ovulation.

The pubertal change in LH output is driven by an increased pulsatile release of gonadotropin-releasing hormone (GnRH) from the hypothalamus [5]. Because $\mathrm{GnRH}$ neurons are capable of producing and releasing $\mathrm{GnRH}$ long before puberty, the pubertal changes in $\mathrm{GnRH}$ activity are primarily due to changes in the transsynaptic balance of activating versus repressing neuronal and glial inputs to GnRH neurons [5]. The initiation of puberty has been hypothesized to result from the removal of a central "brake" [6]. According to this hypothesis, the secretory activity of GnRH neurons is predominantly under transsynaptic inhibitory control during the infantile period. There are some species differences: while the inhibitory transsynaptic control of GnRH neurons is primarily provided by GABA neurons in primates and rodents [7, 8], NPY neurons are inhibitory in primates [9] and excitatory in rodents [10-15]. The strength of the opioid inhibitory tone diminishes at the time of puberty in rodents [16-20], and RFamide-related peptide-containing neurons seem to be involved in the inhibition of mouse $\mathrm{GnRH}$ neuron pulse frequency during infancy [21], pubertal delay induced by dexamethasone [22], or advancement induced by bisphenol A [23]. Overall, when central inhibition is lifted at puberty, there are increased excitatory inputs to the GnRH network that result in increased GnRH release $[5,24]$.

Robust excitatory inputs to $\mathrm{GnRH}$ release are provided by glutamatergic neurons $[25,26]$ as well as a family of peptides known as kisspeptins [27-30]. All kisspeptins are derived from the same kisspeptin precursor that is the product of the KISS1/Kiss1 gene [31,32]. Kisspeptins are vital for puberty to occur, since mutations in Kiss1 and inactivating mutations in its cognate receptor (Kiss $1 r$ ) GPR54) result in infertility and a lack of puberty $[33,34]$. Lastly, glial cells contribute to the hypothalamic control of puberty $[35,36]$ by releasing small molecules (e.g., ATP, E2, and PGE2) and growth factors, as well as through cell-cell interactions that require direct glia-GnRH neuron contact [35, 37, 38], enhancing GnRH release (Fig. 1).

The primary transsynaptic mechanism controlling pulsatile GnRH release is thought to be the coordinated activity of a subset of neurons of the arcuate nucleus (ARC) called KNDy neurons $[39,40]$, so named because they produce kisspeptin, NKB, and dynorphin [39, 41].
KNDy neurons release NKB, which acts upon other KNDy cells, ultimately stimulating kisspeptin release [39, 41]. NKB and kisspeptin are released in a rhythmic manner that is primarily determined by the inhibitory effect of dynorphin on NKB release [39, 41]. Direct evidence for a role of KNDy neurons in pulsatile LH release was recently provided [42]. There is a second population of kisspeptin neurons located in the anteroventral periventricular nucleus (AVPV) of rodents [43]. These AVPV neurons are necessary for the preovulatory surge of gonadotropins [43] and also innervate the ARC in mice [44], suggesting a possible role of AVPV kisspeptin neurons in the onset of puberty.

Despite the importance of this transsynaptic regulatory mechanism, recent evidence suggests the existence of a molecular mechanism that controls the timing of puberty by epigenetically regulating the transcriptional activity of neurons involved in stimulating $\mathrm{GnRH}$ release [45-48]. There are no studies describing the epigenetic changes in the inhibitory transsynaptic control mechanism of the juvenile to pubertal transition. This review will focus mostly on the epigenetic control of kisspeptin neurons (mainly KNDy neurons of the ARC) during the juvenile to pubertal transition.

\section{Epigenetic Regulation of Gene Expression}

To allow the long chains of DNA to be packed into eukaryotic nuclei, cells wrap DNA around histone octamers in a structure called chromatin. When this structure is condensed (aka heterochromatin), it is mostly inactive or transcriptionally repressed. In contrast, in the "open" state (aka euchromatin), the transcriptional machinery has free access to DNA for gene expression. The regulation of chromatin states is controlled by a variety of chromatin-modifying enzymes that modify both histones or DNA itself. These epigenetic modifications induce chromatin remodeling that alters gene expression and ultimately impacts cellular phenotypes. DNA methylation is the most commonly studied epigenetic modification, whereas the greatest diversity of modifications occurs on histones, the tails of which can undergo methylation, acetylation, ubiquitination, phosphorylation, sumoylation, crotonylation, deimination, butyrylation, ADP ribosylation, propionylation, formylation, hydroxylation, and $\mathrm{O}-\mathrm{GlcNAcylation}$.

Epigenetic modifying enzymes can be divided into 3 broad categories: epigenetic writers add epigenetic marks onto DNA or histones that are removed by epigenetic 


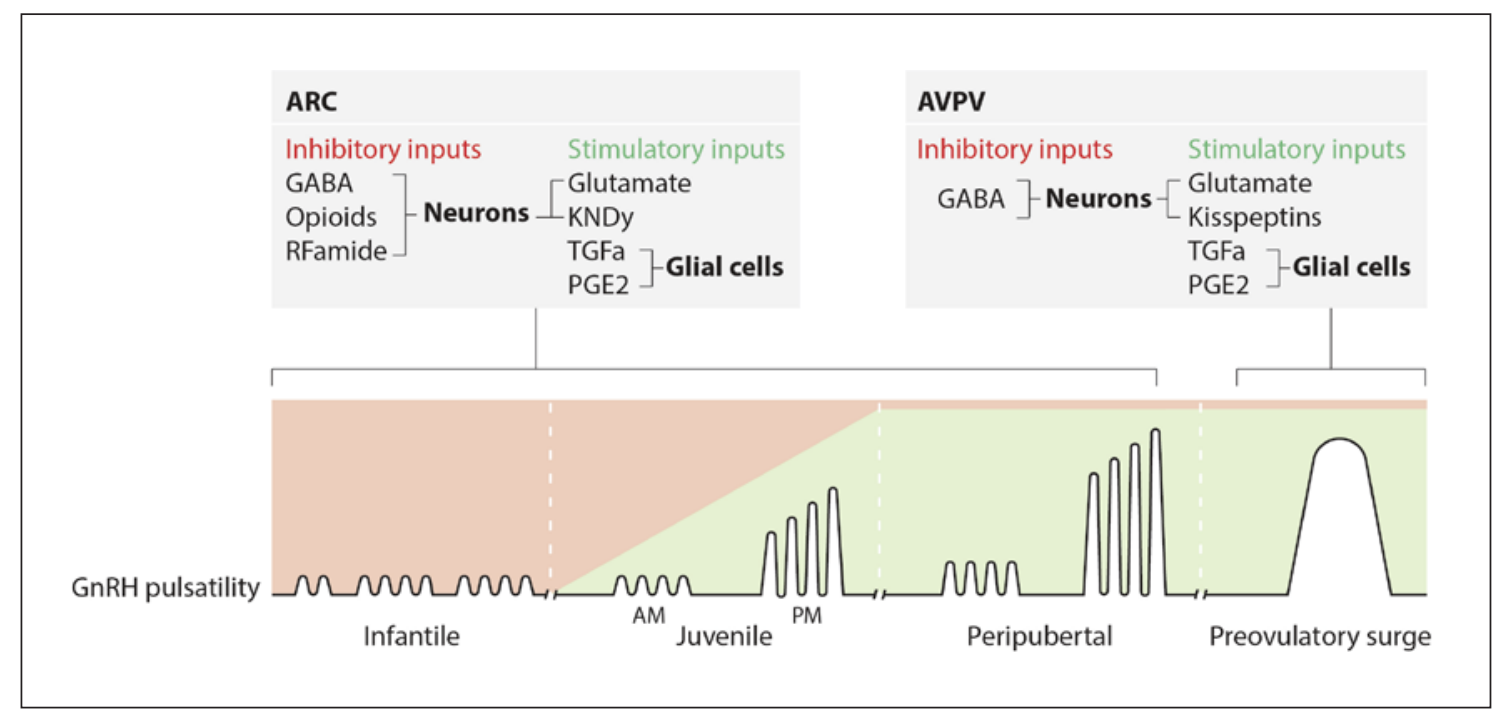

Fig. 1. Hypothalamic regulation of pulsatile GnRH release. The control of puberty is exerted by excitatory and inhibitory transsynaptic inputs to GnRH neurons. The current concept claims that the initiation of puberty implicates a shift from a mainly inhibitory to a stimulatory mode of control. This results in the diurnal activation of pulsatile $\mathrm{GnRH}$ release, leading to increased $\mathrm{LH}$ pulsatility, which is the first endocrine manifestation of puberty. Changes in pulsatile GnRH release are due to decreased inhibitory

erasers, while epigenetic readers recognize these marks and recruit other modifying enzymes and transcription factors. This review will focus on the epigenetic modifying enzymes/processes that have been shown to impact the neuroendocrine control of pubertal development (Fig. 2).

\section{DNA Methyltransferases as Epigenetic Writers}

The most studied epigenetic modification of DNA in mammalian cells is the covalent addition of a methyl group to the $\mathrm{C} 5$ position of the cytosine of the dinucleotide sequence CpG $[49,50]$ by DNA methyltransferases (DNMTs), resulting in the formation of 5-methylcytosine (5-mC). The presence of 5-mC in gene promoter regions promotes the recruitment of methyl-binding proteins that ultimately induce heterochromatin formation and gene silencing [51]. Oxidation of 5-mC by the TET family of dioxygenase enzymes produces 5-hydroxymethylcytosine $(5-\mathrm{hmC})[52,53]$, an epigenetic modification linked with active gene transcription $[54,55]$. The balance between these posttranslational modifications neurotransmission (GABA, opioids, RFamide) and concomitant increased activation of stimulatory neuronal (glutamate, kisspeptins) and glial (TGFa, PGE2) networks that operate within the ARC of the hypothalamus. These neuronal and glial systems affect $\mathrm{GnRH}$ pulsatility by predominantly targeting $\mathrm{GnRH}$ nerve terminals reaching the median eminence. The preovulatory surge of gonadotropins is triggered by the positive feedback of estradiol on AVPV kisspeptin neuronal activation.
(PTMs) depends on the enzymatic activities of DNMTs and TET. Although DNMT1 functions in maintaining basal DNA methylation, DNMT3a and DNMT3b are required for de novo methylation [49].

Gonadal steroids impact neuronal sexual differentiation in the neonatal rodent brain, generating differences that later influence adult reproductive physiology and behavior. The preoptic area, which is involved in sexual and maternal behavior, is highly regulated by estradiol. DNA methylation of the estrogen receptor alpha (ERa) gene has been shown to influence the estrogen-dependent sexual differentiation of the preoptic area in rodents [56] as determined between birth and 3 weeks of life in the mouse. Although some portions of the ERa promoter show a DNA methylation pattern that does not correlate with gene expression [57], other portions of the promoter exhibit DNA methylation with good correlation to gene expression [58], suggesting that the overall changes are confined and limited to specific CpGs in portions of the $5^{\prime}$ flanking region of the ERa promoter.

The expression of the Kiss1 gene in the AVPV area is sexually dimorphic [59]. While AVPV Kiss1 expression is higher in adult females than in males [60], the level of CpG 
Fig. 2. Chromatin structure and the epigenetic code. Heterochromatin is a tightly packed combination of DNA and histone octamers that is associated with less active gene transcription. Euchromatin is less condensed and associated with active gene transcription. Epigenetic writers (brown hexagons) modify the amino acid residues of histone tails, building the histone code at DNA regulatory regions. Epigenetic readers (blue semi-circles) bind to these epigenetic marks and help recruit transcription factors and other epigenetic modifiers. Epigenetic erasers (yellow circles) catalyze the removal of epigenetic marks. The balance of these enzymatic pathways, and thus the balance between hetero- and euchromatin, is what renders a gene in active or silent state.

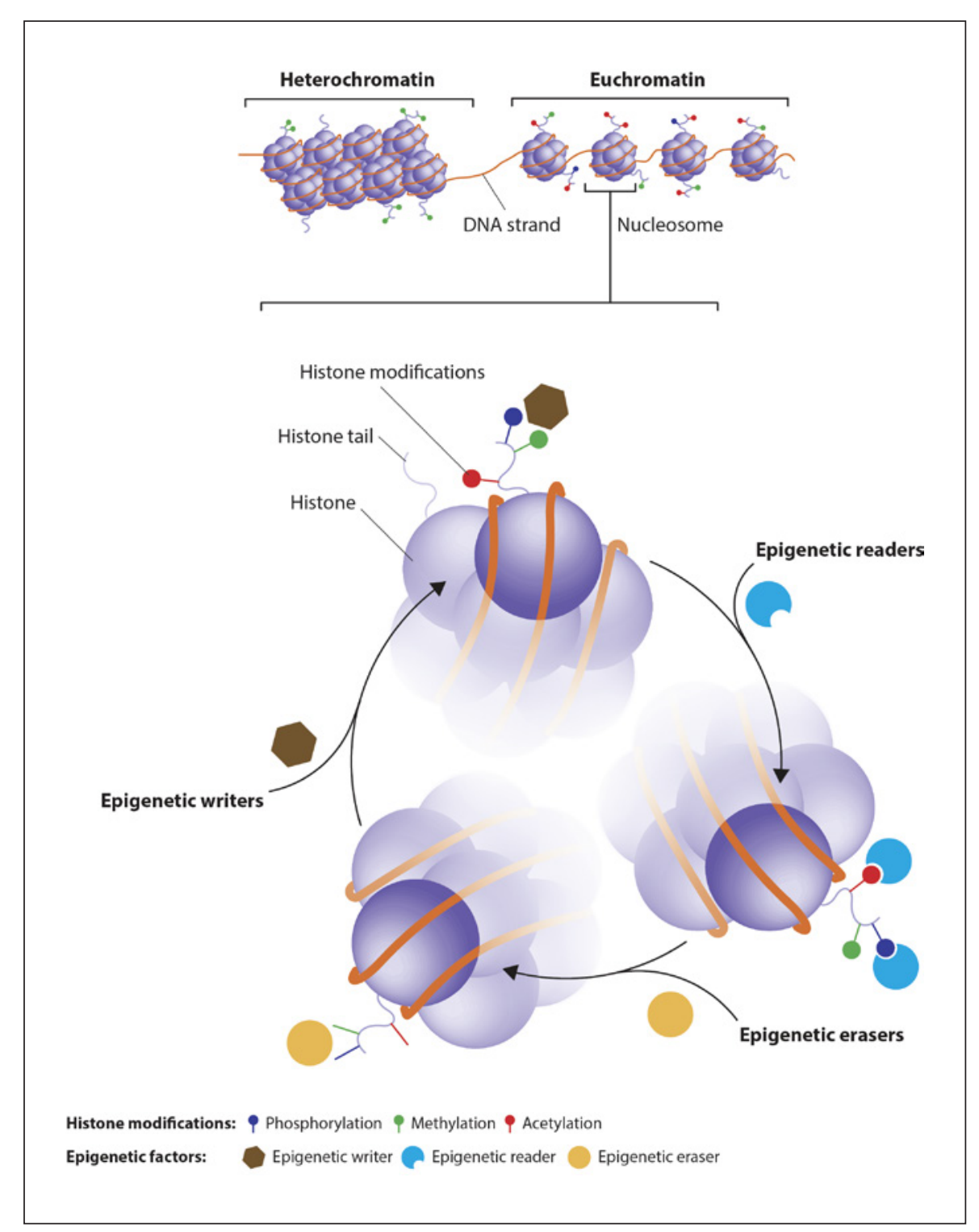

methylation at the promoter region is higher in females than in males [60]. Although counterintuitive, it has been shown that if DNA methylation is associated with silencer regulatory regions, then the recruitment of methyl-binding proteins and the formation of heterochromatin block the recruitment of transcriptional repressors, leading to an upregulation of gene expression $[51,60]$.

Comparative studies of DNA methylation using wholegenome bisulfite sequencing with RNA sequencing (RNAseq) demonstrated that changes in DNA methylation at promoter regions, as well as introns and untranslated regions, influence gene expression in the goat hypothalamus during the onset of puberty [61]. Furthermore, studies per- formed in nonhuman primate cultured GnRH neurons show that there is a decrease in methylation throughout development at multiple CpG sites upstream of the GNRH transcription starting site, indicating that the loss of methylation of regulatory regions of the GNRH gene eliminates its repression, facilitating $G N R H$ transcription [62]. As a result of this deregulation, GNRH mRNA expression increases between 14 and 18 days in in vitro cultures, reaching a maximum peptide release that agrees with the observed decrease in DNA methylation [62].

The existence of a pubertal brake is now a widely accepted concept [6]. During the prepubertal period, the secretory activity of $\mathrm{GnRH}$ neurons is under transsynap- 


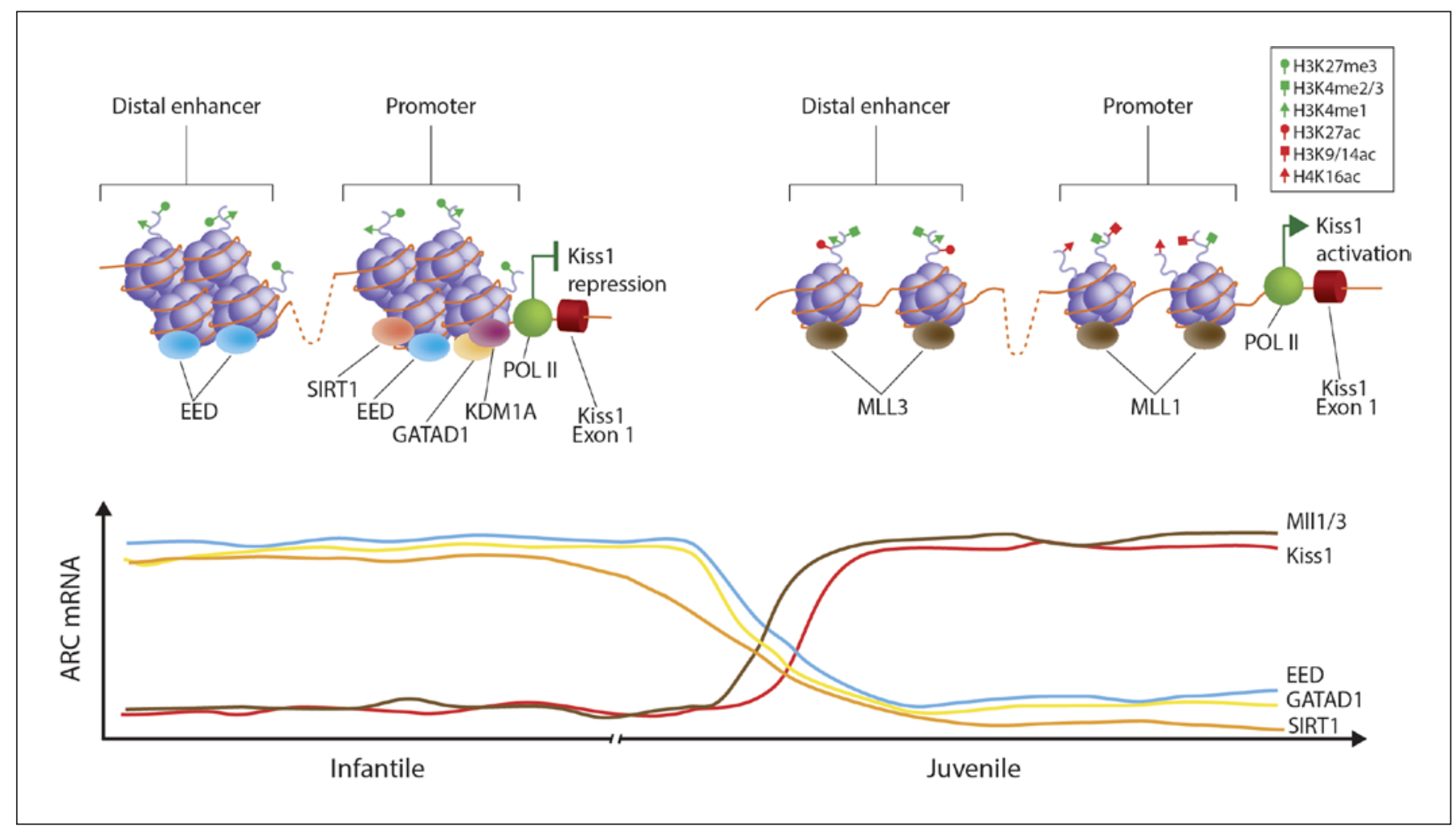

Fig. 3. Diagram depicting the changes in histone marks and epigenetic enzymes at the promoter region of the Kiss1 gene during the infantile to pubertal transition. During the infantile period, when LH pulsatility is low, the expression of several epigenetic repressors (Eed, GATAD1, and SIRT1) is elevated in the ARC. The presence of these epigenetic repressors at the Kiss 1 promoter/enhancer region produces a histone landscape associated with transcriptional repression (high levels of $\mathrm{H} 3 \mathrm{~K} 27 \mathrm{me} 3$ and low levels of $\mathrm{H} 3 \mathrm{~K} 4 \mathrm{me} 3, \mathrm{H} 3 \mathrm{~K} 9 / 14 \mathrm{ac}$, and H4K16ac). As a result of this, Kiss1

tic inhibitory control. At the onset of puberty, this inhibition is lifted, resulting in the reactivation of $\mathrm{GnRH}$ release [63]. Since the Kiss1 gene is one of the primary puberty activators whose expression increases during the infantile to pubertal transition, we hypothesized that during the infantile period, there should be a high expression of transcriptional repressors, and the expression of repressors should diminish as puberty unfolds, allowing for Kiss 1 mRNA levels to increase. In an attempt to identify mRNA expression and DNA methylation changes in the rat ARC during the infantile to pubertal transition, we observed reduced expression of 2 members of the Polycomb group $(\mathrm{PcG})$ of epigenetic repressors, Eed and $\mathrm{Cbx} 7$, while methylation of their promoter regions increased [45]. Later, we determined that the $\mathrm{PcG}$ proteins maintain low ARC Kiss 1 expression during the infantile period, and as pu- expression remains low. As puberty progresses, the expression of these epigenetic repressors diminishes, while the expression of members of the TrxG of epigenetic activators increases. Increased binding of MLL1 and MLL3 to the Kiss1 promoter and enhancer region, respectively, shifts the epigenetic landscape of the Kiss 1 regulatory region into a more active state (low levels of H3K27me3 and high levels of $\mathrm{H} 3 \mathrm{~K} 4 \mathrm{me} 3, \mathrm{H} 3 \mathrm{~K} 9 / 14 \mathrm{ac}$, and $\mathrm{H} 4 \mathrm{~K} 16 \mathrm{ac})$. This results in increased recruitment of RNA polymerase 2 and enhanced Kiss 1 expression at puberty.

berty unfolds, PcG expression decreases, allowing for Kiss1 expression to increase [45]. These results suggest that de novo methyltransferases, such as DNMT3a and DNMT3b, could be responsible for the reduction in PcG protein expression at puberty. More research is needed to identify the gene networks that are controlled by these enzymes and to determine how they are targeted to specific loci throughout the genome.

\section{PcG Proteins as Epigenetic Writers}

In mammals, $\mathrm{PcG}$ proteins form two primary repressive complexes (PRC1 and PRC2) [64, 65]. Gene silencing by $\mathrm{PcG}$ proteins begins with the recruitment of the PRC2 complex to Polycomb response elements (PREs) and the 
induction of trimethylation of histone $\mathrm{H} 3$ at lysine 27 (H3K27me3), a mark associated with silent chromatin [66]. H3K27me3 is subsequently recognized by CBX members of the PRC1 complex that bind to this modification through their chromodomain, producing a robust repressive complex $[64,65,67]$.

In an effort to understand the role of PcG transcriptional repressors during pubertal development and using the Kiss 1 gene as prototype, we showed that $2 \mathrm{im}$ portant PcG members, Eed and $C b x 7$, are expressed in ARC kisspeptin neurons and associate with the Kiss 1 promoter during the prepubertal period [45]. Moreover, as puberty approaches, $\mathrm{PcG}$ association to the Kiss 1 promoter decreases, inducing a reorganization of the chromatin landscape associated with increased levels of $\mathrm{H} 3 \mathrm{~K} 9 \mathrm{ac}, \mathrm{H} 3 \mathrm{~K} 14 \mathrm{ac}$, and $\mathrm{H} 3 \mathrm{~K} 4 \mathrm{me} 3$, all epigenetic marks associated with gene activation. Finally, as expected by these changes, Kiss $1 \mathrm{mRNA}$ levels increase, allowing puberty to progress [45].

As the repressive writers of the $\mathrm{PcG}$ are removed from the Kiss 1 promoter region, the chromatin hyperacetylation observed at puberty could be due to increased histone acetyltransferase (HAT) and/or decreased histone deacetylase enzymatic activity. Similarly, the increased trimethylation of histone 3 at lysine 4 could also be due to the decreased activity of erasers, such as histone demethylases, and/or the increased activity of writers, such as histone methyltransferases. One of the candidates for this activity is the Trithorax group (TrxG) of epigenetic writers due to their recognized PcG-antagonizing activity $[64,68]$ (Fig. 3).

\section{TrxG Proteins as Epigenetic Writers}

The TrxG proteins are evolutionary conserved chromatin modifiers that are classified into 3 classes: the first class of proteins methylates histone tails; the second class contains ATP-dependent chromatin remodeling factors, including "readers" of histone methylation marks; and the third class binds to specific DNA regions and is comprised of histone modifiers, chromatin remodelers, and other unclassified proteins [69]. TrxG proteins counteract the repressive effect of $\mathrm{PcG}$ proteins by adding the activating $\mathrm{H} 3 \mathrm{~K} 4 \mathrm{me} 3$ epigenetic mark at gene regulatory regions. The increased $\mathrm{H} 3 \mathrm{~K} 4 \mathrm{me} 3$ mark is mediated by either the complex of proteins associated with Set1 (COMPASS) or by COMPASS-like complexes, named after the first methyltransferase, SET1, discovered in yeast $[68,69]$. The protein complexes described to date contain

Chromatin Remodeling Factors in Female

Pubertal Development one of the following methyltransferases at their core: $\mathrm{Su}$ (var)3-9, enhancer of zeste, Trithorax (SET1)A or SET1B, mixed-lineage leukemia 1 (MLL1) or MLL2, and MLL3 or MLL4 [68]. Most importantly, while SET1A/ SET1B COMPASS mediates the deposition of the $\mathrm{H} 3 \mathrm{~K} 4 \mathrm{me} 3$ mark at the promoter regions of active genes [70], MLL1/MLL2 performs this function at promoters that are ready for activation or "bivalent" [71-73], while the MLL3/MLL4 complexes catalyze the activation of enhancer sites [70].

To understand the role of the TrxG complex as an opposing force to the PcG proteins in the increased Kiss 1 expression at the juvenile to pubertal transition, we used siRNA-mediated ARC-specific downregulation of Mll1 mRNA expression. Decreased Mll1 expression induced the loss of MLL1 and reduced H3K4me3 to the Kiss 1 promoter, with a concomitant inhibition of Kiss 1 expression and delayed puberty [47]. Additionally, using a CRISPRCAS9-KRAB-mediated epigenetic remodeling approach to increase the inhibitory $\mathrm{H} 3 \mathrm{~K} 9 \mathrm{me} 3$ histone mark at a novel Kiss1 enhancer site, we inhibited the activity and binding of MLL3 on the Kiss1 enhancer region and were able to block the pubertal rise in Kiss 1 expression and delay pubertal development [47]. These results demonstrate that by applying key histone PTMs, the TrxG is capable of altering the epigenetic landscape of the Kiss 1 promoter/enhancer region from a repressed to an active state at the time of female puberty (Fig. 3).

\section{GATAD1/KDM1A Complex as an Epigenetic Reader/ Eraser}

Our lab has recently shown that some members of the zinc finger (ZNF) family of transcriptional repressors are important for keeping the GnRH pulse generator in check during prepubertal development by preventing the reawakening of $\mathrm{GnRH}$ secretion in nonhuman primates [46]. When KISS1 and TAC3 mRNA expression increases in the rhesus monkey hypothalamus during the juvenilepubertal transition, GATAD1 expression decreases. Additionally, when GATAD1 is overexpressed in the ARC of immature rats, puberty is significantly delayed and the estrous cycle is disrupted [46]. GATAD1, a chromatin reader, recruits KDM1A, a histone eraser that induces the loss of activating $\mathrm{H} 3 \mathrm{~K} 4 \mathrm{me} 2 / 3$ marks at gene promoter regions [74, 75]. Using an in vitro approach, we demonstrated that when GATAD1 is overexpressed, KDM1A recruitment increases to both the KISS1 and TAC3 promoters, inducing a significant reduction in the activating 
H3K4me2/3 marks [46]. These results are in line with the idea that GATAD1 reduces KISS1 and TAC3 gene expression, partially by facilitating the loss of $\mathrm{H} 3 \mathrm{~K} 4 \mathrm{me} 2$ marks from puberty-activating gene promoters via the gain of KDM1A. The decreased association of GATAD1 and KDM1A to the KISS1 and TAC3 regulatory regions and the concomitant increase in $\mathrm{H} 3 \mathrm{~K} 4 \mathrm{me} 2$ abundance detected in the monkey medial basal hypothalamus at the time of puberty support the in vitro results, as well as the notion that there is a mechanism of epigenetic repression that is lost during the reawakening of the $\mathrm{GnRH}$ pulse generator throughout the juvenile-pubertal transition in the rhesus monkey hypothalamus [46] (Fig. 3).

\section{Chromatin Remodeling Factors as Mediators of Environmental Signals}

The epigenetic machinery plays an essential role in developmental programming [76-79], linking early-life changes in energy availability to diverse adult metabolic disorders [77, 79-81]. Since cellular metabolites are used as cofactors of histone PTMs [82], it is likely that alterations in the metabolic state that affect reproductive maturation would use epigenetic mechanisms to modify the expression of specific genes. The sirtuins, a class of histone deacetylases (HDACs) [78, 80, 83, 84], are candidates for assessing epigenetic links between nutritional input and the neuroendocrine control of puberty.

Because SIRT1 enzymatic activity depends on cellular nicotinamide adenine dinucleotide $(\mathrm{NAD}+)$ availability, SIRT1 acts as a fuel-sensing enzyme that can silence gene expression by promoting the loss of activating acetylated histone marks in response to nutrient availability [80,83-86]. In a recent study, we demonstrated that when puberty is delayed under conditions of undernutrition, SIRT1 expression is upregulated in the ARC [48], as observed in other models [87-89]. The opposite result is observed in conditions of overnutrition, where SIRT1 is downregulated and puberty is advanced [48]. The epigenetic eraser SIRT1 affects ARC Kiss 1 promoter chromatin structure by deacetylating histone 4 at lysine 16 (H4K16ac) and histone 3 at lysine 9 (H3K9ac) $[48,80]$, inducing heterochromatin formation and the downregulation of Kiss 1 expression. In addition, SIRT1 participates in PcG protein recruitment to Kiss 1 regulatory regions [48], which has also been shown in other systems [90-94]. These results suggest that SIRT1 may serve as an epigenetic relay between energy balance, gene expression, and reproductive function.

\section{Advanced Puberty and Mutations at the Makorin 3 Locus}

Patients with heterozygous loss-of-function mutations of the makorin 3 (MKRN3) gene have been observed to exhibit precocious puberty of central origin [95-105]. MKRN3 is located in the Prader-Willy syndrome region of chromosome 15q11.2, and because it is a maternally imprinted intronless gene, individuals only inherit the mutation from their fathers [95]. MKRN3 is a zinc finger protein with a $\mathrm{C} 3 \mathrm{HC} 4$ motif called a RING domain that is associated with E3 ubiquitin ligase activity [106]. Ubiquitin ligases transfer ubiquitin from an E2-ubiquitin-conjugating enzyme to target proteins. Mkrn3 is highly expressed in the ARC of juvenile mice, and its expression decreases as puberty progresses, suggesting it has a repressing function on the GnRH network [95]. Makorins have been implicated in the regulation of RNA polymerase 2 activity, suggesting they could be involved in transcriptional and/or epigenetic modes of regulation [107]. In vitro promoter assays have revealed that MKRN3 represses Kiss1 and Tac3 promoter activity [unpubl. data], giving rise to the tantalizing possibility that MKRN3 functions as a transcriptional repressor or even as a repressive epigenetic writer via its ubiquitin ligase activity. Moreover, since both the MKRN3 and GATAD1 repressors show the same expression changes in the ARC, it is possible that both genes could be controlled by a common regulatory pathway or even form part of the same repressive complex. Additional research is needed to determine the role of $M K R N 3$ in the maturation of the hypothalamus and in the pathogenesis of central precocious puberty.

\section{Future Perspectives}

There has been an explosion in the development of new genomic and transcriptomic technologies in the last few years that has helped fuel novel research aimed at understanding the dynamic relationship between the environment, the cellular state, and the epigenome. Some of the new technologies that have emerged include the following. (1) Precision nuclear run-on sequencing (PRO-seq), a technique allowing the expression of nascent mRNAs, enhancer RNAs (eRNAs) and noncoding RNAs to be assessed by detecting changes in the endogenous polymerase activity compared to the expression of all the mRNAs present in a cell at any given time. This technique enables us to determine the precise timing of 
polymerase activation and mRNA synthesis. (2) Assay for transposase-accessible chromatin using sequencing (ATAC-seq) takes advantage of open chromatin regions being easily attacked by the Tn 5 transposase to produce single nucleotide resolution maps of open regulatory elements throughout the genome. This technique is used to identify regulatory regions (enhancer and promoters) associated with gene expression at the single-cell level. (3) Chromosome conformation capture assays are a large variety of assays designed to analyze the spatial organization of the chromatin in the nucleus. Chromosome capture enables the study of promoter-enhancer interactions and long-distance intra- and interchromosomal contacts. The use of these technologies will shed new light on how the cell translates external information into genome changes that have long-lasting effects throughout development.

\section{Statement of Ethics}

The authors have no ethical conflicts to disclose.

\section{Disclosure Statement}

The authors have no conflicts of interest to declare.

\section{Funding Sources}

This study received funding by the National Institutes of Health (1R01HD084542) to A.L. and 8P51OD011092 for the operation of the Oregon National Primate Research Center.

\section{Author Contributions}

C.F.A. and A.L. wrote the manuscript. K.V.-C. prepared the figures.

\section{References}

1 Boyar R, Finkelstein J, Roffwarg H, Kapen S, Weitzman E, Hellman L. Synchronization of augmented luteinizing hormone secretion with sleep during puberty. N Engl J Med. 1972 Sep;287(12):582-6.

2 Plant TM. 60 years of neuroendocrinology: the hypothalamo-pituitary-gonadal axis. J Endocrinol. 2015 Aug;226(2):T41-54.

3 Urbanski HF, Ojeda SR. The juvenile-peripubertal transition period in the female rat: establishment of a diurnal pattern of pulsatile luteinizing hormone secretion. Endocrinology. 1985 Aug;117(2):644-9.

4 Urbanski HF, Ojeda SR. Gonadal-independent activation of enhanced afternoon luteinizing hormone release during pubertal development in the female rat. Endocrinology. 1987 Sep;121(3):907-13.

5 Ojeda SR, Terasawa E. Neuroendocrine regulation of puberty. In: Pfaff D, Arnold A, Etgen A, Fahrbach S, Moss R, Rubin R, editors. Hormones, Brain and Behavior. Volume 4. New York: Elsevier; 2002. pp. 589-659.

6 Grumbach MM, Styne DM. Puberty: Ontogeny, neuroendocrinology, physiology, and disorders. In: Wilson JD, Foster DW, editors. Williams Textbook of Endocrinology. 8th ed. Philadelphia: W.B. Saunders, Co.; 1992. pp. 1139-221

7 Terasawa E, Fernandez DL. Neurobiological mechanisms of the onset of puberty in primates. Endocr Rev. 2001 Feb;22(1):111-51.

8 Herbison AE, Moenter SM. Depolarising and hyperpolarising actions of $\mathrm{GABA}(\mathrm{A})$ receptor activation on gonadotrophin-releasing hormone neurones: towards an emerging consensus. J Neuroendocrinol. 2011 Jul;23(7): 557-69.
9 El Majdoubi M, Sahu A, Ramaswamy S, Plant TM. Neuropeptide Y: A hypothalamic brake restraining the onset of puberty in primates. Proc Natl Acad Sci USA. 2000 May;97(11):6179-84.

10 Minami S, Frautschy SA, Plotsky PM, Sutton SW, Sarkar DK. Facilitatory role of neuropeptide $\mathrm{Y}$ on the onset of puberty: effect of immunoneutralization of neuropeptide $\mathrm{Y}$ on the release of luteinizing hormone and luteinizing-hormone-releasing hormone. Neuroendocrinology. 1990 Jul;52(1):112-5.

11 Sutton SW, Mitsugi N, Plotsky PM, Sarkar DK. Neuropeptide Y (NPY): a possible role in the initiation of puberty. Endocrinology. 1988 Oct;123(4):2152-4.

12 Crowley WR, Kalra SP. Neuropeptide Y stimulates the release of luteinizing hormone-releasing hormone from medial basal hypothalamus in vitro: modulation by ovarian hormones. Neuroendocrinology. 1987 Aug;46(2):97-103.

13 Sar M, Sahu A, Crowley WR, Kalra SP. Localization of neuropeptide-Y immunoreactivity in estradiol-concentrating cells in the hypothalamus. Endocrinology. 1990 Dec;127(6):2752-6.

14 Sahu A, Phelps CP, White JD, Crowley WR, Kalra SP, Kalra PS. Steroidal regulation of hypothalamic neuropeptide $\mathrm{Y}$ release and gene expression. Endocrinology. 1992 Jun;130(6):3331-6.

15 Minami S, Sarkar DK. Central administration of neuropeptide $\mathrm{Y}$ induces precocious puberty in female rats. Neuroendocrinology. 1992 Dec;56(6):930-4.

16 Leposavic G, Cover PO, Buckingham JC. In vivo and in vitro studies on the opioidergic control of the secretion of gonadotrophin-releasing hormone and luteinizing hormone in sexually immature and adult male rats. Neuroendocrinology. 1991 Jun;53(6):579-88.
17 Sirinathsinghji DJ, Motta M, Martini L. Induction of precocious puberty in the female rat after chronic naloxone administration during the neonatal period: the opiate 'brake' on prepubertal gonadotrophin secretion. J Endocrinol. $1985 \mathrm{Feb} ; 104(2)$ :299-307.

18 Ieiri T, Chen HT, Meites J. Effects of morphine and naloxone on serum levels of luteinizing hormone and prolactin in prepubertal male and female rats. Neuroendocrinology. 1979;29(4):288-92.

19 Schulz R, Wilhelm A, Pirke KM, Herz A. Regulation of luteinizing hormone secretion in prepubertal male and female rats. Life Sci. 1982 Nov;31(20-21):2167-70.

20 Schulz R, Wilhelm A, Pirke KM, Gramsch C, Herz A. Beta-endorphin and dynorphin control serum luteinizing hormone level in immature female rats. Nature. 1981 Dec; 294(5843):757-9.

21 Glanowska KM, Burger LL, Moenter SM. Development of gonadotropin-releasing hormone secretion and pituitary response. J Neurosci. 2014 Nov;34(45):15060-9.

22 Soga T, Dalpatadu SL, Wong DW, Parhar IS. Neonatal dexamethasone exposure downregulates GnRH expression through the $\mathrm{GnIH}$ pathway in female mice. Neuroscience. 2012 Aug;218:56-64.

23 Losa-Ward SM, Todd KL, McCaffrey KA, Tsutsui K, Patisaul HB. Disrupted organization of RFamide pathways in the hypothalamus is associated with advanced puberty in female rats neonatally exposed to bisphenol A. Biol Reprod. 2012 Aug;87(2):28.

24 Ojeda SR. The mystery of mammalian puberty: how much more do we know? Perspect Biol Med. 1991;34(3):365-83. 
25 Ojeda SR, Skinner MK. Puberty in the rat. In: Neill JD, editor. The Physiology of Reproduction. 3rd ed. San Diego: Academic Press/Elsevier; 2006. pp. 2061-126.

26 Plant TM, Witchel SF. Puberty in nonhuman primates and humans. In: Neill JD, editor. The Physiology of Reproduction. 3rd ed. San Diego: Academic Press/Elsevier; 2006. pp. 2177-230.

27 Shahab M, Mastronardi C, Seminara SB, Crowley WF, Ojeda SR, Plant TM. Increased hypothalamic GPR54 signaling: a potential mechanism for initiation of puberty in primates. Proc Natl Acad Sci USA. 2005 Feb; 102(6):2129-34.

28 d'Anglemont de Tassigny X, Colledge WH. The role of kisspeptin signaling in reproduction. Physiology (Bethesda). 2010;25(4):207-17.

29 Oakley AE, Clifton DK, Steiner RA. Kisspeptin signaling in the brain. Endocr Rev. 2009 Oct;30(6):713-43.

30 Kauffman AS, Clifton DK, Steiner RA. Emerging ideas about kisspeptin- GPR54 signaling in the neuroendocrine regulation of reproduction. Trends Neurosci. 2007 Oct; 30(10):504-11.

31 Kotani M, Detheux M, Vandenbogaerde A, Communi D, Vanderwinden JM, Le Poul E, et al. The metastasis suppressor gene KiSS-1 encodes kisspeptins, the natural ligands of the orphan G protein-coupled receptor GPR54. J Biol Chem. 2001 Sep;276(37):34631-6.

32 Ohtaki T, Shintani Y, Honda S, Matsumoto H, Hori A, Kanehashi K, et al. Metastasis suppressor gene KiSS- 1 encodes peptide ligand of a G-protein-coupled receptor. Nature. 2001 May;411(6837):613-7.

33 Topaloglu AK, Tello JA, Kotan LD, Ozbek MN Yilmaz MB, Erdogan S, et al. Inactivating KISS1 mutation and hypogonadotropic hypogonadism. N Engl J Med. 2012 Feb;366(7):629-35.

34 de Roux N, Genin E, Carel JC, Matsuda F, Chaussain JL, Milgrom E. Hypogonadotropic hypogonadism due to loss of function of the KiSS1-derived peptide receptor GPR54. Proc Natl Acad Sci USA. 2003 Sep;100(19):10972-6.

35 Prevot V. Glial-neuronal-endothelial interactions are involved in the control of $\mathrm{GnRH}$ secretion. J Neuroendocrinol. 2002 Mar;14(3): 247-55.

36 Ojeda SR, Ma YJ, Dziedzic B, Prevot V. Astrocyte-neuron signaling and the onset of female puberty. In: Bourguignon JP, Plant TM, editors. The Onset of Puberty in Perspective. Amsterdam: Elsevier Science B.V.; 2000. pp. 41-57.

37 Clasadonte J, Poulain P, Hanchate NK, Corfas G, Ojeda SR, Prevot V. Prostaglandin E2 release from astrocytes triggers gonadotropinreleasing hormone $(\mathrm{GnRH})$ neuron firing via EP2 receptor activation. Proc Natl Acad Sci USA. 2011 Sep;108(38):16104-9.

38 Lomniczi A, Ojeda SR. A role for glial cells of the neuroendocrine brain in the central control of female sexual development. In: Parpura V, Haydon P, editors. Astrocytes in (Patho) Physiology of the Nervous System. NY: Springer; 2009. pp. 487-511.
39 Navarro VM, Gottsch ML, Wu M, GarcíaGaliano D, Hobbs SJ, Bosch MA, et al. Regulation of NKB pathways and their roles in the control of Kiss1 neurons in the arcuate nucleus of the male mouse. Endocrinology. 2011 Nov;152(11):4265-75.

40 Lehman MN, Coolen LM, Goodman RL. Minireview: kisspeptin/neurokinin B/dynorphin (KNDy) cells of the arcuate nucleus: a central node in the control of gonadotropinreleasing hormone secretion. Endocrinology. 2010 Aug;151(8):3479-89.

41 Wakabayashi Y, Nakada T, Murata K, Ohkura S, Mogi K, Navarro VM, et al. Neurokinin $\mathrm{B}$ and dynorphin $\mathrm{A}$ in kisspeptin neurons of the arcuate nucleus participate in generation of periodic oscillation of neural activity driving pulsatile gonadotropin-releasing hormone secretion in the goat. J Neurosci. 2010 Feb;30(8):3124-32.

42 Beale KE, Kinsey-Jones JS, Gardiner JV, Harrison EK, Thompson EL, Hu MH, et al. The physiological role of arcuate kisspeptin neurons in the control of reproductive function in female rats. Endocrinology. 2014 Mar; 155(3):1091-8.

43 Pinilla L, Aguilar E, Dieguez C, Millar RP, Tena-Sempere M. Kisspeptins and reproduction: physiological roles and regulatory mechanisms. Physiol Rev. 2012 Jul;92(3):1235316.

44 Clarkson J, Boon WC, Simpson ER, Herbison AE. Postnatal development of an estradiolkisspeptin positive feedback mechanism implicated in puberty onset. Endocrinology. 2009 Jul;150(7):3214-20.

45 Lomniczi A, Loche A, Castellano JM, Ronnekleiv OK, Bosch M, Kaidar G, et al. Epigenetic control of female puberty. Nat Neurosci. 2013 Mar; 16(3):281-9.

46 Lomniczi A, Wright H, Castellano JM, Matagne V, Toro CA, Ramaswamy S, et al. Epigenetic regulation of puberty via Zinc finger protein-mediated transcriptional repression. Nat Commun. 2015 Dec;6(1):10195.

47 Toro CA, Wright H, Aylwin CF, Ojeda SR, Lomniczi A. Trithorax dependent changes in chromatin landscape at enhancer and promoter regions drive female puberty. Nat Commun. 2018 Jan;9(1):57.

48 Vazquez MJ, Toro CA, Castellano JM, RuizPino F, Roa J, Beiroa D, et al. SIRT1 mediates obesity- and nutrient-dependent perturbation of pubertal timing by epigenetically controlling Kiss1 expression. Nat Commun. 2018 Oct;9(1):4194.

49 Jaenisch R, Bird A. Epigenetic regulation of gene expression: how the genome integrates intrinsic and environmental signals. Nat Genet. 2003 Mar;33(3s Suppl):245-54.

50 Bjornsson HT, Fallin MD, Feinberg AP. An integrated epigenetic and genetic approach to common human disease. Trends Genet. 2004 Aug;20(8):350-8.

51 Jones PA, Takai D. The role of DNA methylation in mammalian epigenetics. Science. 2001 Aug;293(5532):1068-70.
52 Tahiliani M, Koh KP, Shen Y, Pastor WA, Bandukwala H, Brudno Y, et al. Conversion of 5-methylcytosine to 5-hydroxymethylcytosine in mammalian DNA by MLL partner TET1. Science. 2009 May;324(5929):930-5.

53 Koh KP, Yabuuchi A, Rao S, Huang Y, Cunniff K, Nardone J, et al. Tet1 and Tet2 regulate 5-hydroxymethylcytosine production and cell lineage specification in mouse embryonic stem cells. Cell Stem Cell. 2011 Feb;8(2):20013.

54 Ficz G, Branco MR, Seisenberger S, Santos F, Krueger F, Hore TA, et al. Dynamic regulation of 5-hydroxymethylcytosine in mouse ES cells and during differentiation. Nature. 2011 May;473(7347):398-402.

55 Guo JU, Su Y, Zhong C, Ming GL, Song H. Emerging roles of TET proteins and 5-hydroxymethylcytosines in active DNA demethylation and beyond. Cell Cycle. 2011 Aug;10(16):2662-8.

56 McCarthy MM, Nugent BM. Epigenetic contributions to hormonally-mediated sexual differentiation of the brain. J Neuroendocrinol. 2013 Nov;25(11):1133-40.

57 Schwarz JM, Nugent BM, McCarthy MM. Developmental and hormone-induced epigenetic changes to estrogen and progesterone receptor genes in brain are dynamic across the life span. Endocrinology. 2010 Oct;151(10): 4871-81.

58 Kurian JR, Olesen KM, Auger AP. Sex differences in epigenetic regulation of the estrogen receptor-alpha promoter within the developing preoptic area. Endocrinology. 2010 May; 151(5):2297-305.

59 Kauffman AS, Navarro VM, Kim J, Clifton DK, Steiner RA. Sex differences in the regulation of Kiss1/NKB neurons in juvenile mice: implications for the timing of puberty. Am J Physiol Endocrinol Metab. 2009 Nov; 297(5):E1212-21.

60 Semaan SJ, Dhamija S, Kim J, Ku EC, Kauffman AS. Assessment of epigenetic contributions to sexually-dimorphic Kiss1 expression in the anteroventral periventricular nucleus of mice. Endocrinology. 2012 Apr;153(4): 1875-86.

61 Yang C, Ye J, Li X, Gao X, Zhang K, Luo L, et al. DNA Methylation Patterns in the Hypothalamus of Female Pubertal Goats. PLoS One. 2016 Oct;11(10):e0165327.

62 Kurian JR, Keen KL, Terasawa E. Epigenetic changes coincide with in vitro primate $\mathrm{GnRH}$ neuronal maturation. Endocrinology. 2010 Nov;151(11):5359-68.

63 Terasawa E. Hypothalamic control of the onset of puberty. Curr Opin Endocrinol Diabetes Obes. 1999;6(1):44-9.

64 Simon JA, Kingston RE. Mechanisms of polycomb gene silencing: knowns and unknowns. Nat Rev Mol Cell Biol. 2009 Oct;10(10):697708 .

65 Schwartz YB, Pirrotta V. Polycomb silencing mechanisms and the management of genomic programmes. Nat Rev Genet. 2007 Jan;8(1): 9-22. 
66 Di Croce L, Helin K. Transcriptional regulation by Polycomb group proteins. Nat Struct Mol Biol. 2013 Oct;20(10):1147-55.

67 Otte AP, Kwaks TH. Gene repression by Polycomb group protein complexes: a distinct complex for every occasion? Curr Opin Genet Dev. 2003 Oct; 13(5):448-54.

68 Shilatifard A. The COMPASS family of histone H3K4 methylases: mechanisms of regulation in development and disease pathogenesis. Annu Rev Biochem. 2012;81(1):65-95.

69 Schuettengruber B, Martinez AM, Iovino N, Cavalli G. Trithorax group proteins: switching genes on and keeping them active. Nat Rev Mol Cell Biol. 2011 Nov;12(12):799-814.

$70 \mathrm{Hu}$ D, Gao X, Morgan MA, Herz HM, Smith ER, Shilatifard A. The MLL3/MLL4 branches of the COMPASS family function as major histone H3K4 monomethylases at enhancers. Mol Cell Biol. 2013 Dec;33(23):4745-54.

71 Denissov S, Hofemeister H, Marks H, Kranz A, Ciotta G, Singh S, et al. Mll2 is required for $\mathrm{H} 3 \mathrm{~K} 4$ trimethylation on bivalent promoters in embryonic stem cells, whereas Mll1 is redundant. Development. 2014 Feb;141(3): 526-37.

$72 \mathrm{Wu}$ M, Wang PF, Lee JS, Martin-Brown S, Florens L, Washburn M, et al. Molecular regulation of H3K4 trimethylation by Wdr82, a component of human Set1/COMPASS. Mol Cell Biol. 2008 Dec;28(24):7337-44.

73 Bernstein BE, Mikkelsen TS, Xie X, Kamal M, Huebert DJ, Cuff J, et al. A bivalent chromatin structure marks key developmental genes in embryonic stem cells. Cell. 2006 Apr;125(2): 315-26.

74 Shi Y, Lan F, Matson C, Mulligan P, Whetstine JR, Cole PA, et al. Histone demethylation mediated by the nuclear amine oxidase homolog LSD1. Cell. 2004 Dec;119(7):941-53.

75 Maisonpierre PC, Le Beau MM, Espinosa R 3rd, Ip NY, Belluscio L, de la Monte SM, et al. Human and rat brain-derived neurotrophic factor and neurotrophin-3: gene structures, distributions, and chromosomal localizations. Genomics. 1991 Jul;10(3):558-68.

76 Castellano JM, Bentsen AH, Sánchez-Garrido MA, Ruiz-Pino F, Romero M, Garcia-Galiano $\mathrm{D}$, et al. Early metabolic programming of puberty onset: impact of changes in postnatal feeding and rearing conditions on the timing of puberty and development of the hypothalamic kisspeptin system. Endocrinology. 2011 Sep;152(9):3396-408.

77 Remmers F, Delemarre-van de Waal HA. Developmental programming of energy balance and its hypothalamic regulation. Endocr Rev. 2011 Apr;32(2):272-311.

78 Bellet MM, Sassone-Corsi P. Mammalian circadian clock and metabolism - the epigenetic link. J Cell Sci. 2010 Nov; 123(Pt 22):3837-48.

79 Gabory A, Attig L, Junien C. Developmental programming and epigenetics. Am J Clin Nutr. 2011 Dec;94(6 Suppl):1943S-52S.

80 Vaquero A, Reinberg D. Calorie restriction and the exercise of chromatin. Genes Dev. 2009 Aug;23(16):1849-69.
81 Choi SW, Friso S. Epigenetics: A New Bridge between Nutrition and Health. Adv Nutr. 2010 Nov; $1(1): 8-16$

82 Cheung P, Allis CD, Sassone-Corsi P. Signaling to chromatin through histone modifications. Cell. 2000 Oct;103(2):263-71.

83 Shoba B, Lwin ZM, Ling LS, Bay BH, Yip GW, Kumar SD. Function of sirtuins in biological tissues. Anat Rec (Hoboken). 2009 Apr; 292(4):536-43.

84 Ruderman NB, Xu XJ, Nelson L, Cacicedo JM, Saha AK, Lan F, et al. AMPK and SIRT1: a long-standing partnership? Am J Physiol Endocrinol Metab. 2010 Apr;298(4):E751-60.

85 Mulligan P, Yang F, Di Stefano L, Ji JY, Ouyang J, Nishikawa JL, et al. A SIRT1-LSD1 corepressor complex regulates Notch target gene expression and development. Mol Cell. 2011 Jun;42(5):689-99.

86 Vaquero A, Scher M, Erdjument-Bromage H, Tempst P, Serrano L, Reinberg D. SIRT1 regulates the histone methyl-transferase SUV39H1 during heterochromatin formation. Nature. 2007 Nov;450(7168):440-4.

87 Cakir I, Perello M, Lansari O, Messier NJ, Vaslet CA, Nillni EA. Hypothalamic Sirt1 regulates food intake in a rodent model system. PLoS One. 2009 Dec;4(12):e8322.

88 Dietrich MO, Antunes C, Geliang G, Liu ZW, Borok E, Nie Y, et al. Agrp neurons mediate Sirt1's action on the melanocortin system and energy balance: roles for Sirt1 in neuronal firing and synaptic plasticity. J Neurosci. 2010 Sep;30(35):11815-25.

89 Ramadori G, Lee CE, Bookout AL, Lee S, Williams KW, Anderson J, et al. Brain SIRT1: anatomical distribution and regulation by energy availability. J Neurosci. 2008 Oct;28(40): 9989-96.

90 Furuyama T, Banerjee R, Breen TR, Harte PJ. SIR2 is required for polycomb silencing and is associated with an $\mathrm{E}(\mathrm{Z})$ histone methyltransferase complex. Curr Biol. 2004 Oct;14(20): 1812-21.

91 Chopra VS, Mishra RK. To SIR with Polycomb: linking silencing mechanisms. BioEssays. 2005 Feb;27(2):119-21.

92 Hussain M, Rao M, Humphries AE, Hong JA, Liu F, Yang M, et al. Tobacco smoke induces polycomb-mediated repression of Dickkopf-1 in lung cancer cells. Cancer Res. 2009 Apr;69(8):3570-8.

93 Pruitt K, Zinn RL, Ohm JE, McGarvey KM, Kang SH, Watkins DN, et al. Inhibition of SIRT1 reactivates silenced cancer genes without loss of promoter DNA hypermethylation. PLoS Genet. 2006 Mar;2(3):e40.

94 O'Hagan HM, Wang W, Sen S, Destefano Shields C, Lee SS, Zhang YW, et al. Oxidative damage targets complexes containing DNA methyltransferases, SIRT1, and polycomb members to promoter CpG Islands. Cancer Cell. 2011 Nov;20(5):606-19.
95 Abreu AP, Dauber A, Macedo DB, Noel SD Brito VN, Gill JC, et al. Central precocious puberty caused by mutations in the imprinted gene MKRN3. N Engl J Med. 2013 Jun; 368(26):2467-75.

96 Settas N, Dacou-Voutetakis C, Karantza M, Kanaka-Gantenbein C, Chrousos GP, Voutetakis A. Central precocious puberty in a girl and early puberty in her brother caused by a novel mutation in the MKRN3 gene. J Clin Endocrinol Metab. 2014 Apr;99(4):E647-51.

97 Jeong HR, Lee HS, Hwang JS. Makorin ring finger 3 gene analysis in Koreans with familial precocious puberty. J Pediatr Endocrinol Metab. 2017 Oct;30(11):1197-201.

98 Grandone A, Capristo C, Cirillo G, Sasso M, Umano GR, Mariani M, et al. Molecular Screening of MKRN3, DLK1, and KCNK9 Genes in Girls with Idiopathic Central Precocious Puberty. Horm Res Paediatr. 2017; 88(3-4):194-200.

99 Grandone A, Cirillo G, Sasso M, Capristo C, Tornese G, Marzuillo P, et al. MKRN3 levels in girls with central precocious puberty and correlation with sexual hormone levels: a pilot study. Endocrine. 2018 Jan;59(1):203-8.

100 Christoforidis A, Skordis N, Fanis P, Dimitriadou M, Sevastidou M, Phelan MM, et al. A novel MKRN3 nonsense mutation causing familial central precocious puberty. Endocrine. 2017 May;56(2):446-9.

101 Brito VN, Latronico AC. Underdiagnosis of central precocious puberty in boys with lossof-function mutations of MKRN3. J Pediatr. 2017 Apr;183:202-3.

102 Simsek E, Demiral M, Ceylaner S, Kurel B. Two Frameshift Mutations in MKRN3 in Turkish Patients with Familial Central Precocious Puberty. Horm Res Paediatr. 2017; 87(6):405-11.

103 Bessa DS, Macedo DB, Brito VN, França MM, Montenegro LR, Cunha-Silva M, et al. High Frequency of MKRN3 Mutations in Male Central Precocious Puberty Previously Classified as Idiopathic. Neuroendocrinology. 2017;105(1):17-25.

104 Känsäkoski J, Raivio T, Juul A, Tommiska J. A missense mutation in MKRN3 in a Danish girl with central precocious puberty and her brother with early puberty. Pediatr Res. 2015 Dec;78(6):709-11.

105 de Vries L, Gat-Yablonski G, Dror N, Singer A, Phillip M. A novel MKRN3 missense mutation causing familial precocious puberty. Hum Reprod. 2014 Dec;29(12):2838-43.

106 Böhne A, Darras A, D’Cotta H, Baroiller JF, Galiana-Arnoux D, Volff JN. The vertebrate makorin ubiquitin ligase gene family has been shaped by large-scale duplication and retroposition from an ancestral gonad-specific, maternal-effect gene. BMC Genomics. 2010 Dec;11(1):721.

107 Omwancha J, Zhou XF, Chen SY, Baslan T, Fisher CJ, Zheng Z, et al. Makorin RING finger protein 1 (MKRN1) has negative and positive effects on RNA polymerase II-dependent transcription. Endocrine. 2006 Apr;29(2):363-73. 